\title{
Content of Trace Elements in Plant Raw Material
}

\author{
A.V. Fyodorov \\ Department of Introduction and Acclimatization of Plants \\ Federal state budgetary institution of science "Federal \\ Udmurt Research Center, Ural Branch Russian Academy of \\ Sciences" \\ Izhevsk, Russia \\ udmgarden@mail.ru
}

\author{
O.A. Ardasheva \\ Department of Introduction and Acclimatization of Plants \\ Federal state budget institution of science" Federal Udmurt \\ Research Center, Ural Branch, Russian Academy of \\ Sciences" \\ Izhevsk, Russia \\ o.ardashewa@yandex.ru
}

\author{
D.A. Zorin \\ Department of Introduction and Acclimatization of Plants \\ Federal state budgetary institution of science "Federal Udmurt Research Center, Ural Branch, Russian Academy of \\ Sciences" \\ Izhevsk, Russia \\ zor-d@yandex.ru
}

\begin{abstract}
The paper deals with the analysis of trace element composition of stevia plant raw material. The stevia plant is able to regulate excess of toxic elements and to selectively accumulate essential elements. The essential element content in the plant raw material does not exceed the acceptable standards regardless of the growing conditions.
\end{abstract}

Keywords—stevia, trace elements, coefficient of translocation.

\section{INTRODUCTION}

It is known that trace elements can act as activators or inhibitors of the processes of growth, development and regulation of plant productivity. Mineral components of a plant emphasize its therapeutic importance and allow using a specific species for drug creation [7].

Worldwide attention of scientists and drug manufacturers is shifting from synthetic to natural components. Interest in stevia has arisen due to the increasing demand of mankind in the sweeteners of plant origin [13].

As a component of plant metabolism mineral substances complement and enhance the healing effects on the body. The balance of macro- and microelements in medicinal plants is formed as a result of functioning of complex multiphase mechanisms for the concentration and accumulation of these substances that are affected by various factors, including the species specificity of the plant. For the vast majority of elements, their biological role is determined [11].

The physiological role of trace elements in plants is a part of solving a general problem of mineral nutrition of organisms and normal processes of metabolism and synthesis of biologically active substances (BAS). Microelements contribute to the production of biologically active substances in plants: vitamins, flavonoids, tannin and many other pharmacologically active compounds [10].

There are studies on the content of chemical elements in the tissues of stevia. However, they submitted incomplete information, that is the coefficient of translocation important for growth and development of plants was not considered.
The purpose of this paper is to analyze and research trace elements in soil and stevia plant raw material grown in different environmental conditions. The translocation ratio of studied plants is calculated.

\section{EXPERIMENTAL PART}

The object of the study is vegetative organs of stevia plants grown in different regions of Udmurtia.

Stevia is a herbaceous perennial with annually dying and regrowing stems. The underground part has a form of a thick fleshy rhizome. Overground stems are slender, pubescent, much branched in upper part, up to $150 \mathrm{~cm}$. At the tips of stems, there are paniculate inflorescences with small gathered in little corymbs flowers. The leaves are narrow, elongated, in the upper part they are slightly crenate, in the lower part they are plain, cross-opposite, with short petioles. Both sides of the leaves slightly pubescent $[2,4,6]$.

As O.O. Dzyuba noted (1998), the first studies of stevia chemical composition were conducted by the German scientists P. Rasenack and K. Dieterich in 1908-1909. They extracted sweet glycosides from the leaves. These compounds are promising for use as an artificial sweetener for patients with disorders of carbohydrate metabolism [4].

According to A.G. Lyakhovkin (1999), and V.I. Trukhachev and others (2012) leaves are rich in content of micro- and macroelements [8,14].

The research was conducted at the end of the vegetation. We studied the accumulation and distribution of manganese, zinc, iron and copper in various organs and in soils with different soil and climatic conditions.

Samples of plant material were selected concurrently with the soil samples in dry weather. Collecting, drying, and preparation of samples for chemical analysis were carried out according to standard methods.

The content of acid mobile forms of studied metals in the plant raw material, and the concentrations of these metals in individual plant organs, soil samples were determined and analyzed by atomic absorption [9]. 
Soil composition is of particular importance in the analysis of the plant chemical variability. To prepare extracts we used soil samples of the town of Izhevsk sod-podzolic, sandy loam granulometric composition and medium loamy gray forest soil of the village of Nyrgynda in Karakulinskiy district.

In the study of soils and plants, such elements as manganese, zinc, chromium and copper involved in metabolic processes in plants are of principal interest.

Manganese enters the plant in the form of ions $\mathrm{Mn}^{2+}$. The average content of manganese in plants is $0.001 \%$. It is necessary for the normal course of photosynthesis.

The iron enters the plant in the form of $\mathrm{Fe}^{3+}$. Its amount in the plant is $0.08 \%$. Iron is essential for the formation of chlorophyll.

Zinc enters the plant in the form of ions $\mathrm{Zn}^{2+}$. The average content of zinc in plants is $0.002 \%$. Zinc is part of the active centers of some enzymes (particularly enzymes for the synthesis of polyphenols), it plays an important role in the formation of the plant hormone auxin.

Copper enters the plant in the form of ion $\mathrm{Cu}^{2+}$ or $\mathrm{Cu}^{+}$. The average content of copper in plants is $0.0002 \%$. The copper content in plastocyanin is $0.57 \%$. Copper, like iron and manganese, has the property of reversible oxidation and restoration: $\mathrm{Cu}^{2+}+\mathrm{e} \quad \mathrm{Cu}^{+}$.

It should be remembered that trace element functions in the body of plants are various. Higher plants may contain elevated concentrations of chemical elements without any external signs, which creates a danger by their consumption. Due to the significance of chemical element concentration in plants, it is possible to evaluate the state of the environment in the region [3].

Analysis of plant raw material collected on the territory of the town of Izhevsk and village of Nyrgynda, allowed us to identify some features of chemical element accumulation in the overground parts of stevia.

\section{RESULTS OF THE STUDY AND THEIR DISCUSSION}

According to the study of trace elements in the leaves, stems, roots and soil of different ecological zones, it is found that stevia plants grown on different areas differ in levels of the studied chemical elements (table. 1).

In the stevia leaves collected from different ecological zones, the content of elements does not exceed MPC.

In soil samples of Izhevsk, in comparison with the conventionally ecologically clean district of the village of Karakulino, the content of the elements is higher, and, in addition, there was excessive MPC of zinc 1.56 times and 1.36 times, and copper - 3.2 times.

With the element concentration increase in the soil, its concentration in the plant grows to a certain limit. The high content of $\mathrm{Mn}$ is observed in the leaves of stevia, regardless of the method of reproduction and place of cultivation. In the cultivation areas being studied (with seed method of propagation), the Fe content in stevia leaves is high. Roots often contain more $\mathrm{Zn}$ than the above-ground parts, especially if the plant is grown on the soil rich in $\mathrm{Zn}$. With the optimal content of $\mathrm{Zn}$ in the soil, this element can travel from the roots and accumulate in the upper parts of plants [5].

TABLE I. CONTENT OF MICROELEMENTS IN STEVIA PLANTS AND SOIL, MG/KG

\begin{tabular}{|c|c|c|c|c|c|c|}
\hline $\begin{array}{c}\text { Place of } \\
\text { cultivatio } \\
\mathbf{n}\end{array}$ & $\begin{array}{l}\text { Method of } \\
\text { reproductio } \\
\text { n }\end{array}$ & $\begin{array}{c}\text { Plant } \\
\text { raw } \\
\text { material } \\
\mathrm{s}\end{array}$ & Mn & $\mathbf{F e}$ & $\mathbf{Z n}$ & $\begin{array}{l}\mathbf{C} \\
\mathbf{u}\end{array}$ \\
\hline \multirow{8}{*}{ Izhevsk } & \multirow{4}{*}{ seed } & leaves & 382.6 & 933.5 & $\begin{array}{c}30 . \\
7\end{array}$ & $\begin{array}{l}1 . \\
2\end{array}$ \\
\hline & & stems & 89.0 & 66.4 & $\begin{array}{c}18 . \\
7\end{array}$ & $\begin{array}{l}1 . \\
4\end{array}$ \\
\hline & & roots & 115.5 & 230.7 & $\begin{array}{c}25 . \\
0\end{array}$ & $\begin{array}{l}2 . \\
3\end{array}$ \\
\hline & & $\begin{array}{c}\text { roots in a } \\
\text { month }\end{array}$ & 40.1 & 83.0 & $\begin{array}{c}22 . \\
3\end{array}$ & $\begin{array}{l}2 . \\
7\end{array}$ \\
\hline & \multirow{4}{*}{ vegetative } & leaves & 383.2 & 730.6 & $\begin{array}{c}38 . \\
5\end{array}$ & $\begin{array}{l}2 . \\
3\end{array}$ \\
\hline & & stems & 40.7 & 63.4 & $\begin{array}{c}14 . \\
5\end{array}$ & $\begin{array}{l}2 . \\
2\end{array}$ \\
\hline & & roots & 42.8 & 76.3 & $\begin{array}{c}25 . \\
8\end{array}$ & $\begin{array}{c}2 . \\
5\end{array}$ \\
\hline & & $\begin{array}{c}\text { roots in a } \\
\text { month }\end{array}$ & 22.7 & 22.7 & $\begin{array}{c}20 . \\
2\end{array}$ & $\begin{array}{l}3 . \\
8\end{array}$ \\
\hline \multirow{8}{*}{$\begin{array}{c}\text { vill. } \\
\text { Nyrgynda }\end{array}$} & \multirow{4}{*}{ seed } & leaves & 144.4 & 256.1 & $\begin{array}{c}14 . \\
6\end{array}$ & $\begin{array}{l}1 . \\
2\end{array}$ \\
\hline & & stems & 33.1 & 76.6 & 9.0 & $\begin{array}{l}1 . \\
0\end{array}$ \\
\hline & & roots & 83.9 & 989.8 & 5.5 & 0. \\
\hline & & $\begin{array}{c}\text { roots in a } \\
\text { month }\end{array}$ & 12.5 & 171.4 & $\begin{array}{c}13 . \\
1\end{array}$ & $\begin{array}{l}3 . \\
2\end{array}$ \\
\hline & \multirow{4}{*}{ vegetative } & leaves & 164.4 & 710.2 & $\begin{array}{c}16 . \\
0\end{array}$ & $\begin{array}{l}1 . \\
8\end{array}$ \\
\hline & & stems & 27.5 & 165.5 & 9.4 & $\begin{array}{l}1 . \\
4\end{array}$ \\
\hline & & roots & 20.4 & 303.9 & $\begin{array}{c}12 . \\
3\end{array}$ & $\begin{array}{l}1 . \\
1\end{array}$ \\
\hline & & $\begin{array}{c}\text { roots in a } \\
\text { month }\end{array}$ & 17.3 & 108.8 & $\begin{array}{c}23 . \\
9\end{array}$ & $\begin{array}{c}2 . \\
1\end{array}$ \\
\hline \multicolumn{3}{|c|}{ MPC } & - & - & 50 & 10 \\
\hline \multicolumn{2}{|c|}{ Izhevsk } & \multirow{2}{*}{ soil } & $\begin{array}{c}1,503 . \\
2\end{array}$ & $\begin{array}{c}5,319 . \\
4\end{array}$ & $\begin{array}{c}36 . \\
0\end{array}$ & $\begin{array}{c}9 . \\
5\end{array}$ \\
\hline vill. I & rgynda & & $\begin{array}{c}1,205 . \\
8\end{array}$ & $\begin{array}{c}2,340 . \\
1\end{array}$ & $\begin{array}{c}31 . \\
5\end{array}$ & $\begin{array}{c}9 . \\
5\end{array}$ \\
\hline \multicolumn{3}{|c|}{ MPC } & 500 & 3,800 & $\begin{array}{c}23 . \\
0\end{array}$ & $\begin{array}{l}3 . \\
0\end{array}$ \\
\hline
\end{tabular}

The concentration of $\mathrm{Zn}$ in the roots of stevia was slightly lower than in the leaves, i.e. the roots did not have barrier function regarding this element. This distribution of $\mathrm{Zn}$ in stevia apparently is due to the lack of its movable forms in the studied soils.

Accumulation character of chemical elements in the overground parts of the stevia plant demonstrates a nonuniform level of essential element accumulation.

The rows of trace element accumulation (according to reducing the content) in above-ground and underground organs of stevia are presented in table 2 .

The results of analyses of stevia overground parts and roots do not depend on the cultivation area and enabled the 
distribution of the studied elements in a row in descending order as follows: $\mathrm{Fe}>\mathrm{Mn}>\mathrm{Zn}>\mathrm{Cu}$.

To determine studied metal accumulation in stevia, we used the coefficient of translocation.

Roots act as a barrier between roots and overground organs, preventing the transfer of many elements in the above-ground parts. This is confirmed by the results of the translocation coefficient calculation.

For the studied elements $(\mathrm{Mn}, \mathrm{Fe}, \mathrm{Zn}, \mathrm{Cu})$ we revealed strong physiological barrier to their transfer to the assimilative and generative organs of plants in the conditions of Izhevsk by using seed method of farming.

TABLE II. ROWS OF ACCUMULATION OF MICROELEMENTS IN THE ABOVE-GROUND AND UNDERGROUND ORGANS OF STEVIA AND THE COEFFICIENT OF TRANSLOCATION

\begin{tabular}{|c|c|c|c|}
\hline $\begin{array}{l}\text { Place of } \\
\text { cultivation }\end{array}$ & $\begin{array}{l}\text { Method of } \\
\text { reproduction }\end{array}$ & $\begin{array}{l}\text { Part of } \\
\text { the plant }\end{array}$ & $\begin{array}{l}\text { The ranges of the } \\
\text { accumulation } \\
\text { The coefficient of } \\
\text { translocation }\end{array}$ \\
\hline \multirow{8}{*}{ Izhevsk } & \multirow{4}{*}{ seed } & leaves & $\begin{array}{l}{\underline{\mathrm{Fe}^{*}}}^{*}>\underline{\mathrm{Mn}}_{4.1}^{*}>\underline{\mathrm{Zn}}_{3}^{*}>\underline{\mathrm{Cu}}^{* *} \\
0.5\end{array}$ \\
\hline & & stems & $\begin{array}{l}{\underline{\mathrm{Mn}^{* *}}}^{* *} \underline{\mathrm{Fe}}_{0.8}^{* *}>\frac{\mathrm{Zn}^{* *}}{0.3}{\underline{\mathrm{Cu}^{* *}}}_{0.8} \\
0.6\end{array}$ \\
\hline & & roots & $\mathrm{Fe}>\mathrm{Mn}>\mathrm{Zn}>\mathrm{Cu}$ \\
\hline & & $\begin{array}{l}\text { roots in a } \\
\text { month }\end{array}$ & $\mathrm{Fe}=\mathrm{Mn}>\mathrm{Zn}>\mathrm{Cu}$ \\
\hline & \multirow{4}{*}{ vegetative } & leaves & 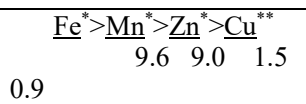 \\
\hline & & stems & $\begin{array}{l}{\underline{\mathrm{Fe}^{* *}}}^{* *}{\underline{\mathrm{Mn}^{*}}}_{0.8}>\underline{\mathrm{Zn}}^{* *}>\frac{\mathrm{Cu}^{*}}{1.0} \\
10.9\end{array}$ \\
\hline & & roots & $\mathrm{Fe}>\mathrm{Mn}>\mathrm{Zn}>\mathrm{Cu}$ \\
\hline & & $\begin{array}{l}\text { roots in a } \\
\text { month }\end{array}$ & $\mathrm{Mn}>\mathrm{Fe}>\mathrm{Zn}>\mathrm{Cu}$ \\
\hline \multirow{8}{*}{$\begin{array}{c}\text { vill. } \\
\text { Nyrgynda }\end{array}$} & \multirow{4}{*}{ seed } & leaves & $\begin{array}{l}\underline{\mathrm{Fe}}^{*}>{\underline{\mathrm{Mn}^{*}}}_{0.3}>\frac{\mathrm{Zn}^{* *}}{1.7}>\frac{\mathrm{Cu}^{* *}}{0.6} \\
0.9\end{array}$ \\
\hline & & stems & $\begin{array}{ll}{\underline{\mathrm{Fe}^{* *}}}^{* *} & \underline{\mathrm{Mn}}_{0.1}^{* *}>\underline{\mathrm{Zn}}^{*}>\underline{\mathrm{Cu}}^{*} \\
1.1 & \\
& \end{array}$ \\
\hline & & roots & $\mathrm{Fe}>\mathrm{Mn}>\mathrm{Zn}>\mathrm{Cu}$ \\
\hline & & $\begin{array}{l}\text { roots in a } \\
\text { month }\end{array}$ & $\mathrm{Fe}>\mathrm{Zn}>\mathrm{Mn}>\mathrm{Cu}$ \\
\hline & \multirow{4}{*}{ vegetative } & leaves & $\begin{array}{ll} & {\underline{\mathrm{Fe}^{*}}}^{*}{\underline{\mathrm{Mn}^{*}}}_{2.3}>\underline{\mathrm{Zn}}^{*}>\mathrm{Cu}^{*} \\
1.6 & \\
1.1 & 1.3\end{array}$ \\
\hline & & stems & $\begin{array}{l}{\underline{\mathrm{Fe}^{* *}}}^{*}>\underline{\mathrm{Mn}}_{0.5}^{*}>\underline{\mathrm{Zn}}^{* *}>\mathrm{Cu}^{*} \\
1.3\end{array}$ \\
\hline & & roots & $\mathrm{Fe}>\mathrm{Mn}>\mathrm{Zn}>\mathrm{Cu}$ \\
\hline & & $\begin{array}{l}\text { roots in a } \\
\text { month }\end{array}$ & $\mathrm{Fe}>\mathrm{Mn}>\mathrm{Zn}>\mathrm{Cu}$ \\
\hline
\end{tabular}

* coefficient of translocation is greater than 1 (bioaccumulation of the element) ** coefficient of translocation less than 1 (physiological barrier to the transfer of element in the tissue of plants)

To assess the intensity of chemical element absorption by stevia plants from the soil the accumulation factors were calculated (table. 3 ).
According to the scale by I. A. Avessalomov (1987), elements of strong accumulation (Accumulation Coefficient $\mathrm{AC})(10>A C>1)$ can include $\mathrm{Zn}$ in the stevia leaves by using vegetative way of growing in the town of Izhevsk. In other studied cases this coefficient, both in the overground and underground organs is of weak accumulation and medium-sized $(1>A C>0.1)$.

TABLE III. COEFFICIENTS OF TRACE ELEMENT ACCUMULATION IN STEVIA PLANTS

\begin{tabular}{|c|c|c|c|c|c|c|}
\hline $\begin{array}{l}\text { Place of } \\
\text { cultivation }\end{array}$ & $\begin{array}{l}\text { Method of } \\
\text { reproduction }\end{array}$ & $\begin{array}{l}\text { Part of } \\
\text { the } \\
\text { plant }\end{array}$ & Mn & $\mathbf{F e}$ & Zn & $\mathrm{Cu}$ \\
\hline \multirow{8}{*}{ Izhevsk } & \multirow{4}{*}{ seed } & leaves & 0.3 & 0.2 & 0.9 & 0.1 \\
\hline & & stems & 0.1 & 0.0 & 0.5 & 0.2 \\
\hline & & roots & 0.1 & 0.0 & 0.7 & 0.3 \\
\hline & & $\begin{array}{l}\text { roots in } \\
\text { a } \\
\text { month }\end{array}$ & 0.0 & 0.0 & 0.6 & 0.3 \\
\hline & \multirow{4}{*}{ vegetative } & leaves & 0.3 & 0.1 & 1.1 & 0.2 \\
\hline & & stems & 0.0 & 0.0 & 0.4 & 0.2 \\
\hline & & roots & 0.0 & 0.0 & 0.7 & 0.3 \\
\hline & & $\begin{array}{l}\text { roots in } \\
\text { a } \\
\text { month }\end{array}$ & 0.0 & 0.0 & 0.6 & 0.4 \\
\hline \multirow{8}{*}{$\begin{array}{c}\text { vill. } \\
\text { Nyrgynda }\end{array}$} & \multirow{4}{*}{ seed } & leaves & 0.1 & 0.1 & 0.5 & 0.1 \\
\hline & & stems & 0.0 & 0.0 & 0.3 & 0.1 \\
\hline & & roots & 0.0 & 0.4 & 0.2 & 0.1 \\
\hline & & $\begin{array}{l}\text { roots in } \\
\text { a } \\
\text { month }\end{array}$ & 0.0 & 0.1 & 0.4 & 0.3 \\
\hline & \multirow{4}{*}{ vegetative } & leaves & 0.1 & 0.3 & 0.5 & 0.2 \\
\hline & & stems & 0.0 & 0.1 & 0.3 & 0.2 \\
\hline & & roots & 0.0 & 0.1 & 0.4 & 0.1 \\
\hline & & $\begin{array}{c}\text { roots in } \\
\text { a } \\
\text { month }\end{array}$ & 0.0 & 0.1 & 0.8 & 0.2 \\
\hline
\end{tabular}

Data on chemical element concentrations were compared with MPC values of specified elements developed for tea and medicinal plants: $\mathrm{Cu}(10 \mathrm{mg} / \mathrm{kg}), \mathrm{Zn}(50 \mathrm{mg} / \mathrm{kg})$ [14]. We found out that the content of these elements in the stevia leaves from the studied areas was much lower than their MPC.

\section{CONCLUSIONS}

The stevia plant is able to regulate the flow of chemical elements that allows them, on the one hand, actively oppose the excessive intake of toxic elements and, on the other hand, selectively accumulate essential elements.

\section{References}

[1] I. A. Avessalomov Geochemical indices in the study of landforms: Textbook, M.: Publishing house of Moscow University, 1987.

[2] V. P. Alekseev, Honey grass Kaa - khe, Bulletin of All - Union Scientific Research Institute of Tea and Subtropical Crops: Vol. 1, Makharadze, 1956, pp. 168-169.

[3] A. P. Vinogradov, Basic patterns in the distribution of microelements between plants and environment, Trace elements in life of plants and animals, M: Nauka, 1985, pp. 7-20.

[4] O. O. Dzyuba, Stevia Rebaudiana (Bertoni), Hemsley - a new source of natural sugar substitute, Vegetable resources, Vol. 34, issue. 2, SPb.: Nauka, 1998, pp. 86-91.

[5] A. Kabata-Pendias, H. Pendias, Trace elements in soils and plants, M.: Mir, 1989. 
[6] Kornienko, A. V., Zhuzhzhalova T. P., Znamenskaya V. V., Bulavin, N.I. Prospective sugar substitute, Sugar beet. 1993. Vol. 1. - P. 35-36.

[7] S. A. Listov, N.V. Petrov, A. P. Arzamastsev, On the content of heavy metals in herbal drugs, Pharmacy, 1992, No. 2, pp. 19-25.

[8] A. G. Lyakhovkin, A. P. Nikolaev, V. B. Uchitel, Stevia is a honey herb, $\mathrm{SPb} .:$ Ves, 1999.

[9] Methodological recommendations, RD 52.18.191-89, Moscow, State Committee for Hydrometeorology of the USSR, 1990.

[10] A.R. Nozdryukhina, N. I. Grinkevich, Violation of microelement metabolism and its correction, Moscow: Publishing House "Nauka", 1980, pp. 74.
[11] V. S. Petukha, E. P. Chebykin, G. M. Fedoseyeva, Study of elemental composition of hemp family nettle, Siberian medical journal, 2008, No. 6, pp. 88-90.

[12] SanPiN, 2.3.2.1078-01. Hygienic safety requirements and nutritive value of food products, M., 2001.

[13] M. A. Sukhanova, Qualitative and quantitative composition of diterpenoid glycosides of Stevia Rebaudiana Bertoni lines under different growing conditions, Botanical research in Kamchatka: Proceedings of sessions I and II of the Kamchatka branch of the Russian Botanical society, Petropavlovsk - Kamchatsky, 2004, pp. 153-156.

[14] V. I. Trukhachev, G. P. Starodubtseva, Y. A. Bezgina, S. I. Lyubaya, M. V. Veselova, Prospects of cultivation of stevia and manufacture of products on its basis, Vestnik APK Stavropol, 2012, Vol. 1(5), pp. 22-25. 